\title{
Physical and sensory characteristics of pellets elaborated with different levels of corn grits and whey protein concentrate
}

\section{Características físicas e sensoriais de pellets elaborados com diferentes teores de grits de milho e de concentrado protéico de soro lácteo}

\author{
Anderson Felicori Fernandes ${ }^{1 *}$, Raul Antônio Viana Madeira ${ }^{1}$, \\ Carlos Wanderlei Piler Carvalho'², Joelma Pereira ${ }^{1}$
}

\author{
${ }^{1}$ Universidade Federal de Lavras/UFLA, Departamento de Ciência dos Alimentos/DCA, Lavras, MG, Brasil \\ ${ }^{2}$ Empresa Brasileira de Pesquisa Agropecuária/Embrapa, Rio de Janeiro, RJ, Brasil \\ *Corresponding author. andersonfelicori@hotmail.com \\ Received in august 28, 2015 and approved in november 30, 2015
}

\begin{abstract}
Whey has proteins of high biological value, which has been used as an ingredient in the elaboration of yogurt, milk beverages and as protein concentrates. Food extrusion stands out as one of the most efficient cooking techniques, allowing a number of product types, from soluble flour to convenience products, such as snacks, which have high acceptability by the consumers. Products processed by extrusion, such as those expanded by frying (pellets), have high carbohydrate content, and its enrichment with protein can favor its nutritional aspect. This study aimed to use the whey protein concentrate (WPC) in combination with corn grits in the preparation of pellets. Absolute density, density of expanded pellets, color, crispness index, and pellet sensory acceptance were determined. For the absolute density, contents from $5 \%$ to $17 \%$ produced denser non-expanded pellets. The higher the WPC content and the temperature of the extruder, the higher the density of the expanded pellets. The crispness index was not altered by the protein content and by the extruder temperature. In the sensory analysis, the preferred samples were the ones with lower WPC levels (5\%). We concluded that higher WPC values in the pellets formulation increased their density, but did not alter color and texture, as well as small WPC levels did not affect the acceptance of snacks.
\end{abstract}

Index terms: Extrusion; sensory; texture.

\begin{abstract}
RESUMO
O soro lácteo possui proteínas de alto valor biológico, e que vem sendo utilizado como ingrediente na elaboração de iogurtes, bebidas lácteas e na forma de concentrados proteicos. A extrusão de alimentos, destaca-se entre as mais eficientes técnicas de cozimento, proporcionando inúmeros tipos de produtos, desde farinhas solúveis a produtos de conveniência como snacks, apresentando alta aceitabilidade pelos consumidores. Produtos processados por extrusão, como os expandidos por fritura (pellets) apresentam teor elevado de carboidratos, e seu enriquecimento com proteína, pode favorecer o aspecto nutricional do mesmo. Neste trabalho, objetivou-se utilizar o concentrado proteico de soro lácteo (WPC) em combinação com o gritz de milho na elaboração de pellets. Foram determinadas a densidade absoluta, densidade dos pellets expandidos, diferença de cor, índice de crocância, além da aceitação sensorial dos pellets. Para a densidade absoluta, teores de 5 a 17\% de WPC deixaram os pellets não- expandidos mais densos. Quanto maior foi o teor de WPC e a temperatura do extrusor, maior foi a densidade dos pellets expandidos. O índice de crocância não foi alterado pelo teor de proteína e temperatura do extrusor. Na análise sensorial, as amostras mais preferidas foram as com menores teores de WPC (5\%). Concluímos que maiores valores de WPC nas formulações dos pellets aumentaram a densidade dos mesmos, mas não alteraram a cor e a textura, assim como pequenos teores de WPC não alteraram a aceitação dos snacks.
\end{abstract}

Termos para indexação: Extrusão; sensorial; textura.

\section{INTRODUCTION}

Whey has proteins of high biological value, which are interesting for the improvement of the nutritional quality of human nourishment (Rankin; Darragh, 2005). In developed countries, whey is wholly used as a product of high aggregated value as an ingredient in the elaboration of yogurts, milky beverages, powdered milk, and other products, because its incorporation doesn't aim only at the improvement of the nutritional aspect, but also at its rheological properties, as a thickening agents whose taste is pleasant (Camejo et al., 1999, Ordonez, 2005).

The food extrusion, regarding its versatility and flexibility, stands out as the most efficient cooking techniques, and is also a method which requires less energy expenditure and of high productivity, allowing a large number of types of products, from soluble flours to 
convenience goods, such as breakfast cereals, snacks and cookies, which present high acceptability by the consumers (Tribelhorn; Harper, 1980; Felows, 2008).

Products processed by extrusion, as the ones expanded directly (snacks) and the ones expanded by frying or microwaves (pellets), present elevated carbohydrate contents, particularly starch, thus being pointed out as co-responsible in promoting obesity through being easier to digest (Alvina; Araya, 2004). However, such products present high acceptability by the consumers, who are attracted by their sensory attributes, such as texture, color, scent, and flavor (Huang, 1995); and, presenting easy digestion, they are important for nutrition, especially the nutrition of poor people, which allows giving the example of the food offered to children in Brazil's public school system. This type of food can be enriched with protein, as a way to favor its nutritional aspect. However, the addition of protein sources, or even fiber sources, tends to reduce the desired properties, such as the airy texture (Seker, 2005). This study aimed to evaluate the effect of varying levels of protein concentrate whey and extrusion temperature on the physical and sensory characteristics of non- expanded extruded (pellets) of corn .

\section{MATERIAL AND METHODS}

The protein concentrate whey powder was purchased from Alibra Ingredientes Ltda, Campinas, SP, in package of $20 \mathrm{~kg}$.

The corn gritz were acquired at GEM Alimentos, Acreúna, GO, in $20 \mathrm{~kg}$ bags.

To analyze the combined effect of the variables: $\%$ of the whey protein concentrate (WPC) and the temperature of the extrusion in the technological characteristics of the extruded (optimize the final product), it was established an experiment, statistically designed in a methodology of response surface of the $2^{\text {nd }}$ order rotable central composite type (Box; Hunter; Hunter, 1978).

The experiment was conducted in a full factorial design $2^{2}$ with two factors or dependent variables (percentage of whey protein concentrate and temperature). This way, in this study 11 treatments were used, being 4 factorials (combinations of the levels -1 and +1 ), 4 axial (one variable in the $\pm \alpha$ level and the other in the 0 level), and three centrals, serving as estimate of the experimental error and to determine the precision of the mathematical model (Cochran; Cox, 1964).

Table 1 shows the design with 11 treatments performed, the encrypted values and the original.
Table 1: Complete design of the pellets experimental design.

\begin{tabular}{ccccc}
\hline \multirow{2}{*}{ Treatments } & \multicolumn{2}{c}{$\begin{array}{c}\text { Coded variable } \\
\text { levels }\end{array}$} & \multicolumn{2}{c}{$\begin{array}{c}\text { Decoded variable } \\
\text { levels }\end{array}$} \\
\cline { 2 - 5 } & X1 & X2 & WPC (\%) & T ( $\left.{ }^{\circ} \mathrm{C}\right)$ \\
\hline 01 & -1 & -1 & 5 & 60 \\
02 & -1 & 1 & 5 & 90 \\
03 & 1 & -1 & 29 & 60 \\
04 & 1 & 1 & 29 & 90 \\
05 & -1.4142 & 0 & 0.03 & 75 \\
06 & 1.4142 & 0 & 33.97 & 75 \\
07 & 0 & -1.4142 & 17 & 53.8 \\
08 & 0 & 1.4142 & 17 & 96.2 \\
09 & 0 & 0 & 17 & 75 \\
10 & 0 & 0 & 17 & 75 \\
11 & 0 & 0 & 17 & 75 \\
\hline X1
\end{tabular}

$\mathrm{X} 1$ = Protein concentrate, WPC (\%).

$\mathrm{X} 2=$ Temperature $\left({ }^{\circ} \mathrm{C}\right)$ of the 3 rd extrusion zone, $\mathrm{T}\left({ }^{\circ} \mathrm{C}\right)$.

The samples of raw material were conditioned to the different levels of protein concentrate (corn grits was replaced by WPC according to the delineation), according to the experimental design and the final humidity content fixed at $37.07 \%$, determined by preliminary tests.

After the determination of initial humidity of the raw material (corn grits and whey protein concentrate) through rapid scale method, the raw material were weighed in plastic bags, according to the formulation, and the amount of added water was according to the sample's initial humidity. After that, the samples were homogenized for 3 minutes and packed for 24 hours and refrigerated $\left(8{ }^{\circ} \mathrm{C}\right)$ in a refrigerator, in order to obtain a more uniform water distribution and absorption.

To the elaboration of the pellets, the single screw extruder of the Brabender brand, model DSE 20DN, coupled with the torque rheometer DCE 330 (Duisburg, Germany), was used, and the parameters used were: screw compression ratio of $2: 1,100 \mathrm{rpm}$ of screw rotation speed and $20 \mathrm{rpm}$ of feeder speed. The laminar matrix used was of $1 \mathrm{~mm}$ thick and $30 \mathrm{~mm}$ wide.

The extruder is equipped with 3 heating zones in its cylinder (1,2 and 3$)$. The fixed temperatures to zones 1 and 2 were of $50^{\circ} \mathrm{C}$ and $100^{\circ} \mathrm{C}$, respectively. The temperature of zone 3 followed the experimental design (Table 1).

The pellets strips were placed in plastic bags and frozen in a freezer, at a $-18{ }^{\circ} \mathrm{C}$ temperature, until the 
moment of the analysis, because they were perishable, because of their high humidity content (34 to $36 \%$ )

To the realization of the analysis, the samples were defrosted at room temperature, manually cut into a size of 3 centimeters and dried in oven with forced airflow circulation at $60{ }^{\circ} \mathrm{C}$ for 6 hours, until reaching humidity of $5 \%$ to $8 \%$. For the sensory analysis, the cut pellets were expanded through frying in soy oil, using an industrial frying pan with temperature fixed at 180 ${ }^{\circ} \mathrm{C}$ for a time that varied from 11 to $20 \mathrm{~s}$. The pellets were dried in oven with forced airflow circulation at $45{ }^{\circ} \mathrm{C}$ for $4 \mathrm{~h}$.

To determine the absolute density of the nonexpanded pellets, a pycnometer model Accupyc 1340 was used, in which an amount of previously weighed pellets was put inside a chamber of known volume. The volume of the sample was determined through the variation of the pressure of the helium gas injected in the chamber. The analysis was done in duplicate and the results were expressed in $\mathrm{g} \mathrm{cm}^{-3}$, according to the methodology Webb (2001).

The bulk density before and after frying was analyzed through the method of weight relation of pellets through their volume measured by the displacement of millet seeds in a graduated cylinder, following the methodology Webb and Orr (1997).

To determine the texture, the texturometer Texture Analyzer TA. HDi (Stable Micro Systems, UK) was used, applying the puncture test (measurement of strength in compression) with the following parameters: cylindrical probe $\mathrm{P} 2$ of $2 \mathrm{~mm}$ diameter and $36 \mathrm{~mm}$ of length, test speed of $1 \mathrm{mms}^{-1}$, after-test speed of $10 \mathrm{~mm} \mathrm{~s}^{-1}$ and distance of $10 \mathrm{~mm}$, after touching the sample, according to the methodology suggested by Bouvier, Bonneville and Gollieus et al. (1997). 6 repetitions were executed for each sample. The obtained data were analyzed by the texture program Tex32, obtaining the strength $(\mathrm{N})$ peak and the area, considering the strength and the distance $(\mathrm{mm})$. The strength peak represents the initial resistance of the geometrical penetration and the hardness of the extruded; and the area below the curve is the energy required to the given displacement. The equations below were used:

Frequency of breaks $(\mathrm{Nsr})=\frac{N o}{d}$

Specific strength of breaks (Fsr) $=\sum \frac{\Delta F}{N o}=$ Average
Compression strength $(\mathrm{F})=\frac{A}{d}$

Work or crispness index $(\mathrm{Wc})=\frac{F}{N s r}$

In which $N O$ is the total number of peaks, $d$ is the distance that the product was compressed $(\mathrm{mm}), \Delta F$ is the applied strength of falling generated for each peak $(\mathrm{N})$ and $A$ is the area below the curve of the strength which provoked the deformation $\left(\mathrm{mm}^{2}\right)$.

The treatments T1, T2, T5, T7, T8 and T12 of pellets with WPC were used for the sensory analysis. They were chosen by a group of experts in sensory analysis, for submitting further expansion and improved physical appearance. They were sensorily evaluated through the acceptance test.

The test was performed under white lights in individual booths. The samples were presented in monadic form, in saucers of white china, coded with numbers of three digits. In this study, the balanced complete blocks design (Macfie et al.,1989). The samples were evaluated according to the acceptance of 95 non-trained consumers, using a structured hedonic scale of 9 scores $(9=$ extremely liked to $1=$ extremely disliked) and the probability of buying using a 5-score scale ( $5=$ definitely would buy to $1=$ definitely wouldn't buy). In the evaluation sheet, it was also requested to the tasters to mention what they best liked and disliked in each sample. The scores obtained in the acceptance test were analyzed through an internal preference map (Nunes; Pinheiro; Bastos, 2011) and the data related to the ones that the tasters mentioned as most liked were analyzed through a principal components analysis. The statistical analysis were executed in the SensoMaker software (Pinheiro; Nunes; Vietoris, 2013).

The model significance was tested by the analysis of variance (ANOVA), using the F distribution test (Box; Wetz, 1973).

The data processing, the statistical analysis and three-dimensional graphs of response surface were performed with help of the version 8.0 of the Statistica computer program

\section{RESULTS AND DISCUSSION}

Figure 1 shows the effect of WPC variable in the absolute density of the pellets, whose contents of 5 to $17 \%$ provided more dense pellets, and thereafter is increased as the protein there was a progressive decrease in density. 


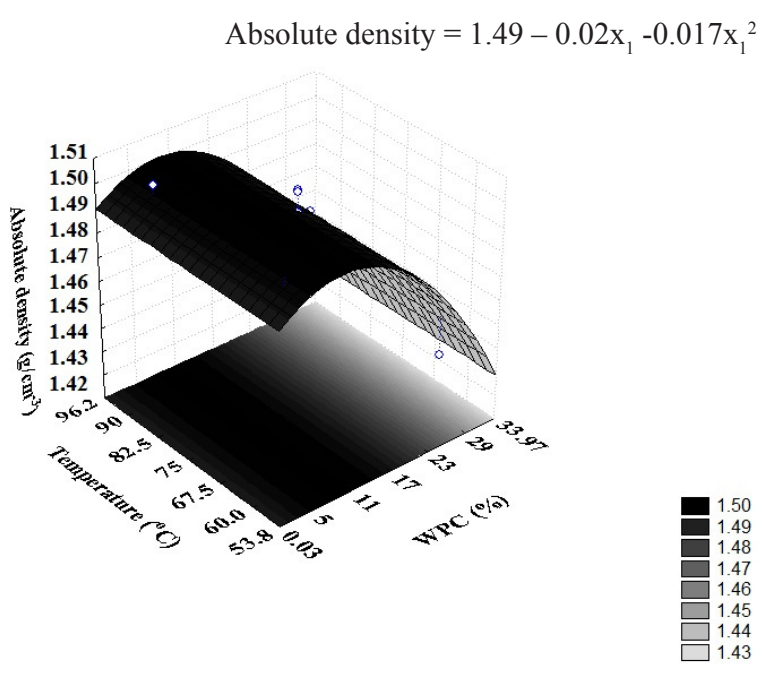

Figure 1: Whey protein concentrate effect on the absolute density of the corn gritz pellets.

The extrusion provides condition of gelatinization of the starch, polymerization of proteins, and transient bond of molecules to form extended arrays (Rossi; Peri, 1980). In the elaboration of intermediate products, or pellets, when leaving the extruder, they presented laminar array (according with the desired format) without expansion, presenting only a small level of gelatinization (Carvalho; Mitchell, 2001), as a consequence of the conditions of high humidity $(37 \%)$, lower temperatures in the extruder $\left(50^{\circ}, 100^{\circ}\right.$ and $75^{\circ} \mathrm{C}$, for the $1^{\mathrm{a}}, 2^{\mathrm{a}}$ and $3^{\mathrm{a}}$ zones, respectively), controlled screw rotation $(100 \mathrm{rpm})$ and short-term permanence in the extruder. Substituting corn gritz for WPC decreases the density of the formed mass, during the extrusion process, caused by the dilutive effect of the starch, decreasing the absolute density of the pellets.

The WPC variables and the temperature did not influence significantly in the apparent density of the nonextended pellets, which presented average value of 1,008 $\mathrm{g} \mathrm{cm}^{-3}$. This value is close to the one obtained by Silva, Carvalho and Andrade (2009) for non-expanded pellets with varied contents of water and sucrose. The pellets, after leaving the extrudor, have thickness and shape according to the array's characteristics, practically no expansion, resulting in close values among them. When comparing the results here obtained with the ones obtained by the absolute density (variation of 1,4362 to $1,5012 \mathrm{~g} \mathrm{~cm}^{3}$ ), it is verified that there is a higher density in the last one. This can be justified by the difference between the used methods. In the absolute density method, the helium gas in the pyctometer device penetrates through the open and closed pores in the pellets, counting them out of the total volume, thus presenting higher density values. The methodology of seed displacement in a cylinder only measures the external volume, not counting pores, irregularities or even all the internal spaces that might exist in the pellets.

Figure 2 represents the effect of the WPC variables and the temperature of the last zone in the extruder in the density of the expanded pellets. It is observed that higher contents of WPC and temperature caused an increase in the pellets density. That can be explained by the fact that higher WPC contents decrease the starch content and its gelatinization during the frying process is one of the main factors in the increasing of the volume and in the consequential decreasing in density. It is verified that density is inversely proportional to expansion, which means, denser products are less airy and less expanded. The expansion is influenced by physicochemical changes that occur during the extrusion, such as the gelatinization degree (Chinnaswamy; Bhattacharya, 1983; Mercier; Feillet, 1975) and the molecular degradation of starch (Cai; Diosady, 1993; Gomez; Aguilera, 1983; Kirby et al., 1988). For this reason, the variables which influence the volume of the expanded are the extrusion temperature, the humidity, the rotation speed and the screw configuration, and array geometry (Bhattacharya; Hanna, 1987; Colonna; Tayeb; Mercier, 1989; Gogoi; Yam, 1994; Owusu-Ansah; Van de Voort; Syanley, 1983). Higher temperatures in the $3^{\text {rd }}$ zone of the extruder might have provoked higher protein denaturation with consequential increase in the protein-protein and protein-starch interactions, harming the expansion.

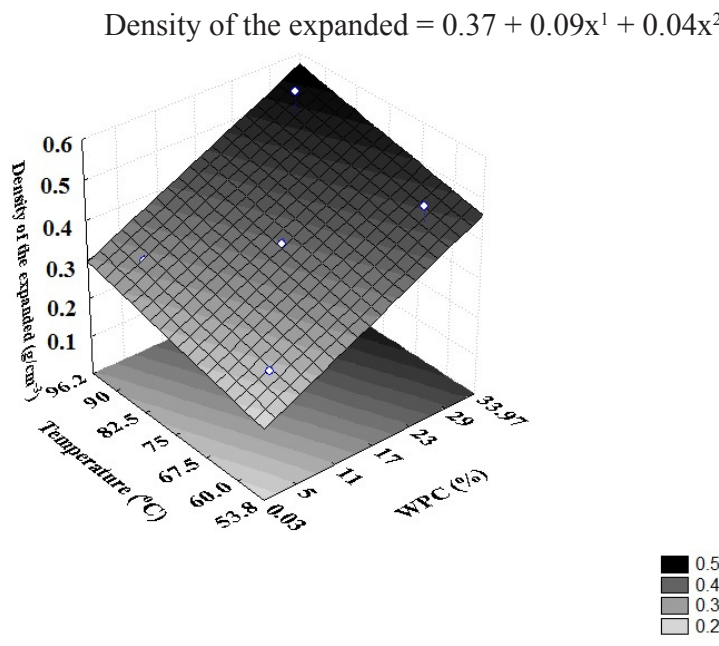

Figure 2: Effect of whey protein concentrate variable (\%) and temperature $\left({ }^{\circ} \mathrm{C}\right)$ on the density of the expanded of the pellets whey protein concentrate (WPC) and corn grits. 
When comparing the density of non-expanded pellets $\left(0,894\right.$ to $\left.1,197 \mathrm{~g} \mathrm{~cm}^{-3}\right)$ with the one of the expanded pellets $\left(0,241\right.$ a $\left.0,5716 \mathrm{~g} \mathrm{~cm}^{-3}\right)$, it is verified a great reduction of the pellets density, fact explained by the frying heat, which causes the starch gelatinization and consequently the expansion of the pellets. According to Dogan and Karwe (2003), the heat absorbed during the frying process of the non-expanded extruded products contributed to the amount of heat needed in converting the starch granules, partially cooked by extrusion, in a swollen structure that is typical in the extrusion process at high temperatures, short amount of time and low water content. The temperature is one of the parameters that contributes to decreasing the density of the starch product and which makes it crunchy, a characteristic that is highly appreciated by the consumers.

Among the factors for sensory acceptability, which are appearance, taste and texture, this last one is the most important descriptor to qualify crunchy products. The puncture test is and instrumental measure for the physical determination of the texture in expanded extruded products, once it simulates the teeth impact while chewing food (Bouvier; Bonneville; Goullieux, 1997). For this reason, the following criteria were used for evaluating the crunchiness of the pellets: frequency of structural breaks (Nsr), specific strength of the structural breaks (Fsr), compression strengths (F) and crunchiness index (Wc).

Only the depending variable Nsr was statistically influenced by the independent variable temperature, but there was no mathematical model that could be well adjusted to the data. The average of the 11 treatments if found on Table 2.

The breaks frequency is the reason between the number of peaks and the pellet thickness. The higher the frequency of breaks, the higher was the number of broken cells in the pellet. According to Mercier, Linko and Harper (1998) products with large expansion normally present a lower hardness, because its internal structure presents bigger cells with thinner walls. The substitution of the corn gritz by the WPC didn't alter the breaks frequency, suggesting that the internal structure of the pellets were not altered by this variable. The temperatures in the $3^{\text {rd }}$ extrusion zone resulted in values that differ from the break frequency, which makes it not possible to indicate a tendency.

Both the specific strength of breaks (Fsr) which represents the mechanical resistance relative to each break (peak) which presented average value of $2.85 \mathrm{~mm}^{-1}$ and the compression strength which presented average value of $4.01 \mathrm{~N}$, which indicates how much strength is needed to compress or break the extruded, did not alter with the substitution of corn gritz by WPC and through the variations of temperature in the $3^{\text {rd }}$ zone of the extruder. A similar result was obtained by Onwulata et al. (2010), in which pellets of pure corn and pellets with $12.5 \%$ of whey protein concentrate at $80 \%$ (the same used in this study) presented Hardness values (the maximum strength needed to break the samples) in texturometer TA-XT2 statistically equal. The results obtained in this study indicate that the starch-protein interactions in the pellets did not alter the pellets' cells' structure, also resulting in values that are equal to the crunchiness index, which presented average value of $1.08 \mathrm{~N} \mathrm{~mm}$.

Chen et al. (1991), working with corn extruded, related that the crunchiness is linked to density, which, by its turn, is linked with the expansion, and that a less dense product has higher crunchiness and is easier to be chewed. However, comparing the density values of the expanded pellets (Figure 2) it is observed that there is a rise in their density while the WPC content and the temperature in the last zone of the extruder are increased, which means, smaller expansion of the pellets occurs under these conditions, results that are not according to the ones obtained for texture, as the pellets crunchiness was not altered.

As for the sensory analysis, technique of preference map, applied in this study, it is a technique which tries to correlate evaluations of consumer's preference to the characteristics of sensory perception in relation to the product, in order to determine how the sensory

Table 2: Frequency of structural breaks (Nsr) of pellets of corn gritz of the 8 treatments (1 to 8 ) and of 3 central points (treatments 9 to 11) according to the WPC content and temperature.

\begin{tabular}{|c|c|c|c|c|c|c|c|c|c|c|c|}
\hline Treatments & 1 & 2 & 3 & 4 & 5 & 6 & 7 & 8 & 9 & 10 & 11 \\
\hline $\operatorname{Nsr}\left(\mathrm{mm}^{-1}\right)^{*}$ & 2.83 & 3.3 & 4.6 & 3.2 & 2.6 & 3.7 & 5.7 & 3.5 & 2.9 & 3.9 & 3.6 \\
\hline
\end{tabular}


characteristics of the product have an effect on how much the consumer liked the product (Gaston et al., 2010).

Figure 3 illustrates the internal preference map of the global impression caused by the pellets with WPC.

It is observed that sample T1 $\left(5 \% \mathrm{WPC}, 60^{\circ} \mathrm{C}\right)$ was the favorite of the consumers, followed by sample T2 $(5 \%$ WPC, $90{ }^{\circ} \mathrm{C}$ ). The results indicate that low WPC contents in the pellets formulation produced in them characteristics that were pleasant to the consumers, outperforming the standard treatment (T5). In common, these samples were the less dense (Figure 2) and, thus, more expanded and aerated.

Still according to the chart in Figure 3, the less preferred samples were samples, T8 $\left(17 \% \mathrm{WPC}, 96,2^{\circ} \mathrm{C}\right)$, T12 $\left(17 \%\right.$ WPC, $\left.75^{\circ} \mathrm{C}\right)$ and T7 $\left(17 \%\right.$ WPC, $\left.53,8^{\circ} \mathrm{C}\right)$, in that order. When comparing these samples with the other analysis, it is found that these samples have in common their higher density, thus presenting lower expansion. This effect can be attributed to the higher WPC content in these treatments, when comparing to $\mathrm{T} 1$ and $\mathrm{T} 2$.

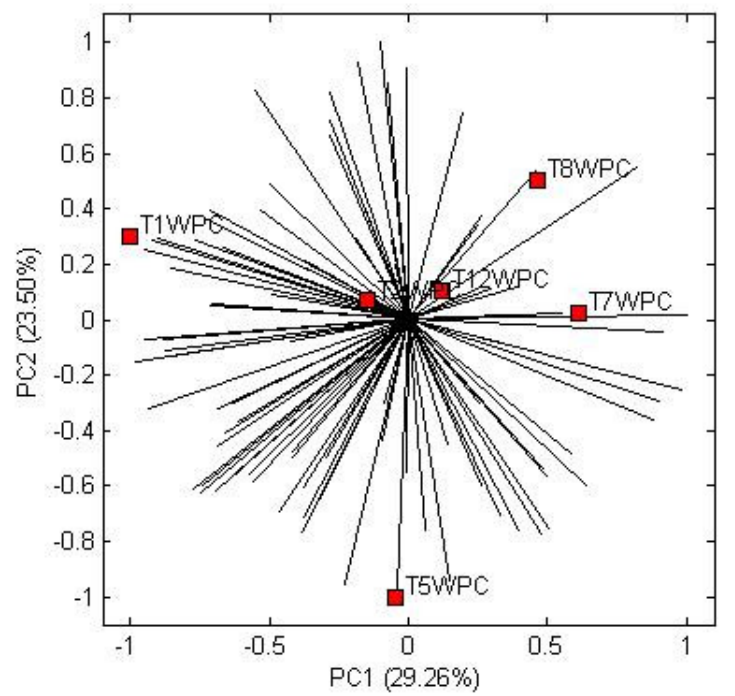

$\mathrm{T} 1\left(5 \%\right.$ WPC e $\left.60^{\circ} \mathrm{C}\right), \mathrm{T} 2\left(5 \%\right.$ WPC e $\left.90^{\circ} \mathrm{C}\right), \mathrm{T} 5\left(0.03 \% \mathrm{WPC}\right.$ e $\left.75^{\circ} \mathrm{C}\right), \mathrm{T} 7$ $\left(17 \%\right.$ WPC e $\left.53.8^{\circ} \mathrm{C}\right)$, T $8\left(17 \%\right.$ WPC e $\left.96.2^{\circ} \mathrm{C}\right)$ e $\mathrm{T} 12\left(17 \%\right.$ WPC e $\left.75^{\circ} \mathrm{C}\right)$.

Figure 3: Internal preference map of the global acceptance of the pellets with WPC.

Although the preference map is one of the most popular marketing research tools, it has limitations, because, in this type of test it is asked to the consumer how much he or she likes the product, and information regarding how they perceive or describe the product are not collected (Lado et al., 2010). In this sense, the check- all-that-apply (CATA) tool has been applied to consumers in order to determine which sensory attribute can be the characteristic of a specific product (Dooley; Lee; Meullenet, 2010). In this study, CATA questions were applied together with the acceptance test, in which the consumers determined the best expression to describe the product, allowing a better perception of its acceptance. Through the analysis of the main components, the answers given by the tasters, of what they liked best in each sample was transformed in coordinates which are expressed in Figure 4.
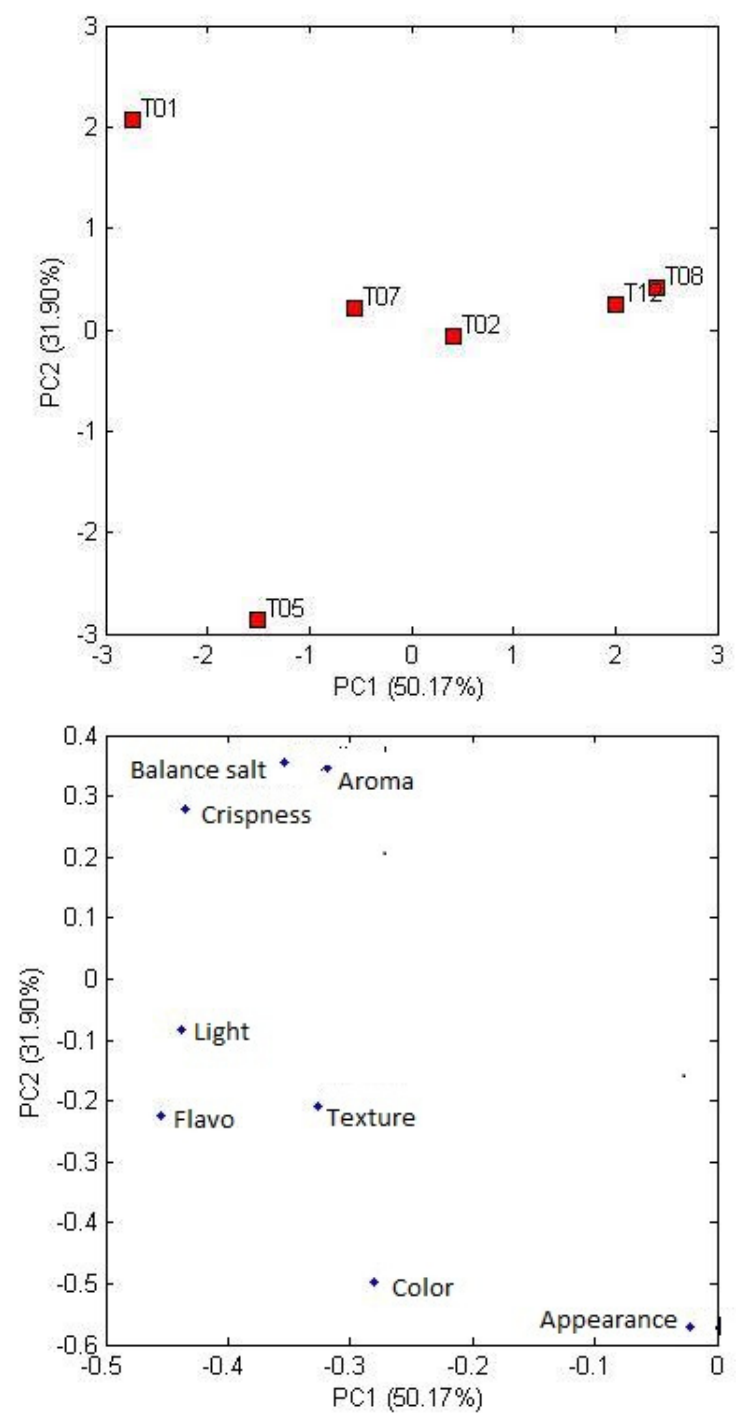

Figure 4: Representation of the samples and the sensory attributes which the consumers say they like in the pellets with WPC. 
Treatments T2 (5\% WPC and $\left.90{ }^{\circ} \mathrm{C}\right)$ and T7 $(17 \%$ WPC e $75^{\circ} \mathrm{C}$ ) has as main liking attributes mentioned by consumers: texture, flavor and being light. However, sample T1 $\left(5 \%\right.$ WPC and $\left.60{ }^{\circ} \mathrm{C}\right)$ was positively related because of its crunchiness, salt balance and scent, this being one of the most preferred sample. The color attribute was the most positively related to sample T5 $(0,03 \%$ WPC and $\left.75^{\circ} \mathrm{C}\right)$. Samples T8 $\left(17 \% \mathrm{WPC}\right.$ and $\left.53.8^{\circ} \mathrm{C}\right)$ and $\mathrm{T} 12$ $\left(17 \%\right.$ WPC and $\left.75^{\circ} \mathrm{C}\right)$ didn't have any positive attribute highly linked to them, which could explain these samples being the least likable by the consumers.

The attributes which the tasters mentioned as least liked in the samples of pellets with WPC is in Figure 5.
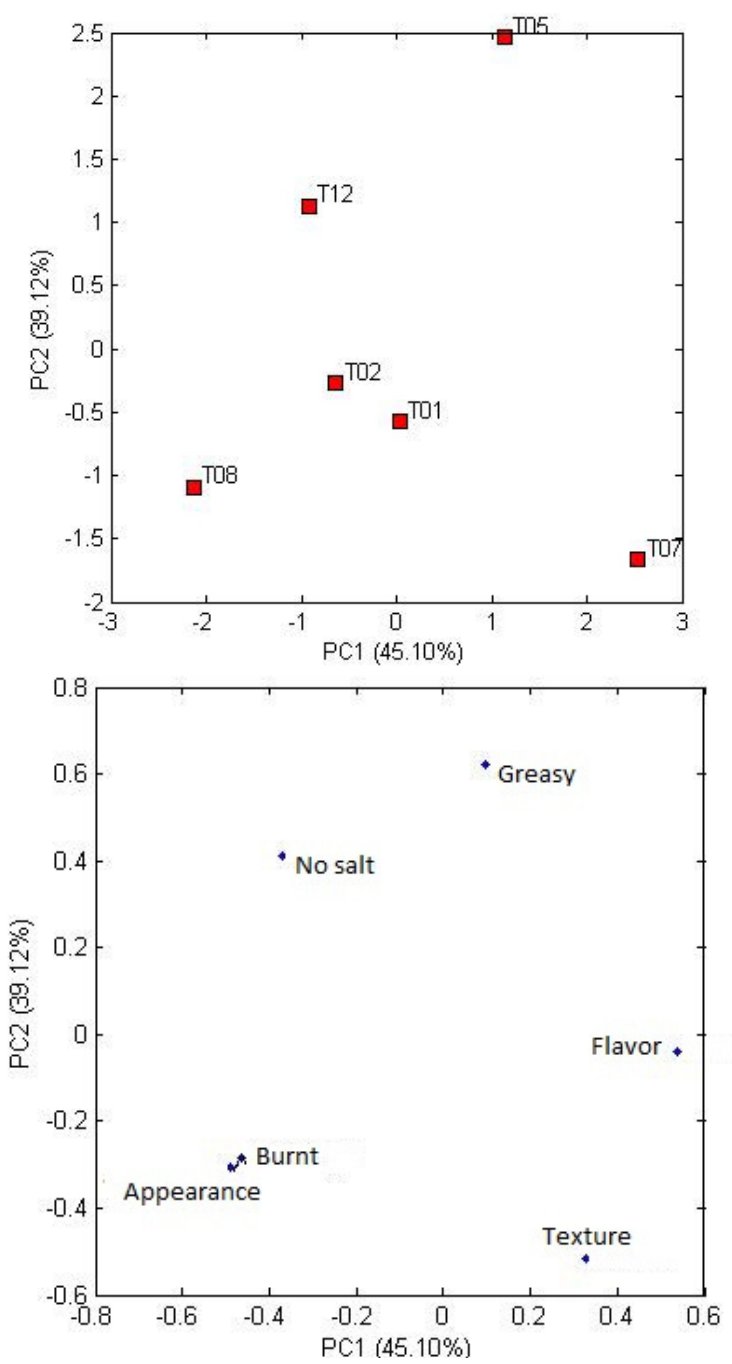

Figure 5: Representation of the samples and the sensory attributes which the consumers say they like the least in the pellets with WPC.
Sample T8 $\left(17 \%\right.$ WPC and $\left.53.8^{\circ} \mathrm{C}\right)$, according to the mentioned items by the tasters as "disliked", was characterized, mainly by the "burnt" and "appearance" attributes. Sample T05 $\left(0.03 \%\right.$ and $\left.75^{\circ} \mathrm{C}\right)$ had the attribute "greasy" as the most mentioned as negative factor, although it didn't harm the good acceptance that this sample received. However, sample T07 (17\% WPC and $53.8^{\circ} \mathrm{C}$ ) was highly linked with "texture" as the least liked attribute, a fact that is according to the results obtained in the density of the expanded (graph 2), in which said treatment was one of the treatments which presented the smaller expansion with consequential higher density. The attributes considered as negative "taste", "burnt" and "appearance" are linked less intensely to treatment T01 (5\% WPC and $\left.60{ }^{\circ} \mathrm{C}\right)$ and more to T02 (5\% WPC and $75^{\circ} \mathrm{C}$ ), a fact justified by these treatments being the ones preferred by the consumers. Finally, the negative attribute "unsalted" was the most mentioned for sample T12 (17\% WPC and $75^{\circ} \mathrm{C}$ ).

In a general way, the crunchiness attribute was the most mentioned as "liked" by the tasters in the acceptance of the pellets. In a lower scale, texture and taste were also mentioned. To the tasters who mentioned as "not liked", the attribute taste was the one with the higher frequency for all the pellet samples.

\section{CONCLUSIONS}

In the experimental condition that the current studied was performed, the obtained results allow the conclusion that the substitution of corn gritz by whey protein concentrate (WPC) until the levels of $17 \%$ and extrusor temperature until $75{ }^{\circ} \mathrm{C}$ produced pellets with good expansion, in which the levels of up to 5\% WPC obtained the best results. The crunchiness index stayed unaltered in any proportion of corn gritz/WPC and temperatures studied in this experiment. The scores in the sensory acceptance test indicated that the pellets with $5 \%$ of WPC had higher acceptance than the standard sample without whey protein, thus proving that the production of pellets with WPC with great technological and sensory quality is perfectly possible.

\section{ACKNOWLEDGMENTS}

The authors thank the Coordenação de Aperfeiçoamento Pessoal de Nível Superior, the Empresa Brasileira de Pesquisa Agropecuária and the Departamento de Ciência dos Alimentos of the Universidade Federal de Lavras. 


\section{REFERENCES}

ALVINA, M.; ARAYA, H. Rapid carbohydrate digestion rate produced lesser short-term satiety in obese preschool children. European Journal of Clinical Nutrition, 58(1):637-642, 2004.

BHATTACHARYA, M.; HANNA, M. A. Kinetics of starch gelatinization during extrusion cooking. Journal of Food Science, 52:764-766, 1987.

BOUVIER, J. M.; BONNEVILLE, R.; GOLLIEUS, A. Instrumental methods for the measurements of extrudate crispness. Agro Food Industry Hi-Tech, 1997. p. 16-19.

BOX, G. E. P.; HUNTER, W. G.; HUNTER, J. S. Statistics for experimenters: An introduction to design, data analysis and model building. New York: John Wiley \& Sons, 1978. $653 p$.

BOX, G. E. P.; WETZ, J. Criteria for judging adequacy of estimation by approximate response function. Wisconsin: University of Wisconsin, 1973. 95p. (Technical report, 9).

CAI, W.; DIOSADY, L. L. Model for gelatinization of wheat starch in a twin-screw extruder. Journal of Food Science, 58:872-887,1993.

CAMEJO, J. et al. El suero en la elaboración de leches fermentados. Alimentaria, 303:31-134, 1999.

CARVALHO, C. W. P.; MITCHELL, J. R. Effect of sucrose on starch conversion and glass transition of nonexpanded maize and wheat extrudates. Cereal Chemistry, 78(3):342-348, 2001.

CHEN, J. et al. Effects of extrusion conditions on sensory properties of corn meal extrudates. Journal of Food Science, 56(1):84-89, 1991.

CHINNASWAMY, R.; BHATTACHARYA, K. R. Studies on expanded rice: physicochemical basis of varietal diferences. Journal of Food Science, 48(6):1600-1603, 1983.

COLONNA, P.; TAYEB, J.; MERCIER, C. Extrusion cooking of starch and starchy products. In: MERCIER, P. C.; LINKO, J. M.; HARPER, J. M. (Ed.). Extrusion cooking. Saint Paul: American Association of Cereal Chemists, 1989. p. 247319.

COCHRAN, W. G.; COX, G. M. Experimental Designs. London: John Wiley \& Sons, 1964. 611p.

DOGAN, H.; KARWE, M. V. Physicochemical properties of quinoa extrudates. Food Science and Technology International, 9(2):101-114, 2003.
DOOLEY, L.; LEE, Y.; MEULLENET, J. The application of checkall-that-apply (CATA) consumer profiling to preference mapping of vanilla ice cream and its comparison to classical external preference mapping. Food Quality and Preference, 21(4):394-401, 2010.

FELLOWS, P. J. Tecnologia do processamento de alimentos: princípios e prática. Tradutor Florencia Cladera Oliveira et al. 2 ed. Porto Alegre: Artmed, 2008. 602p.

GASTON, A. et al. Application of a check-all that-apply question to the development of chocolate milk desserts. Journal of Sensory Studies, 25(1):67-86, 2010.

GOGOI, B. K.; YAM, K. L. Relationships between residence time and process variables in a corotating twin- screw extruder. Journal of Food Engineering, 21(2):177-196, 1994.

GOMEZ, M. H.; AGUILERA, J. M. Changes in the starch fraction during extrusion cooking of corn. Journal of Food Science, 48(2):378-381, 1983.

HUANG, D. P. New perspectiveis on starch and starch perivatives for snack application. Cereal World, 40(8):528531, 1995.

KIRBY, A. R. et al. An experimental study of screw configuration effects in the twin-screw extrusion cooking of maize grits. Journal of Food Engineering, 8(4):247-272, 1988.

LADO, J. et al. Application of a check-all-that-apply question for the evalution of strawberry cultivars from a breding program. Journal of the Science of Food and Agriculture, 90(13):2268-2275, 2010.

MACFIE, H. J. et al. Designs to balance the effect of order of presentation and first-order carry-over effects in hall tests. Journal of Sensory Studies, 4(2):129-148, 1989.

MERCIER, C.; FEILLET, P. Modification of carbohydrate components by extrusion-cooking of cereal products. Cereal Chemistry, 52(3):283-297, 1975.

MERCIER, C.; LINKO, P.; HARPER, J. M. Extrusion cooking. $2^{\text {nd }}$. ed. Saint Paul: American Association of Cereal Chemists, 1998. $471 \mathrm{p}$.

NUNES, C. A; PINHEIRO, A. C. M.; BASTOS, S. C. Evaluating consumer acceptance tests by three-way internal preference mapping obtained by Parallel Factor Analysis (PARAFAC). Journal of Sensory Studies, 26(2):167-174, 2011.

ORDONEZ, J. A. Tecnologia de Alimentos - Alimentos de Origem Animal, v.2, 2005. 279p. 
ONWULATA, C. I. et al. Glycemic potential of extruded barley, cassava, corn, and quinoa enriched with whey proteins and cashew pulp. International Journal of Food Properties, 13(2):338-359, 2010.

OWUSU-ANSAH, J.; VAN DE VOORT, F. R.; STANLEY, S. W. Physico-chemical changes in corn starch as a function of extrusion variables. Cereal Chemistry, 60(4):319-324, 1983.

PINHEIRO, A. C. M.; NUNES, C. A.; VIETORIS, V. SensoMaker: a tool for sensorial characterization of food products. Ciencia e Agrotecnologia, 37(3):199-201, 2013

RANKIN, D.; DARRAGH, A. Dietary protein in an endurance exercise recovery beverage - what is the value of whey? American Dairy Products Institute, 22: 55-69, 2005.

ROSSI, M.; PERI, C. Effects of extrusion cooking on structural and functional characteristics of sunflower protein. In: LINKO, $P$. et al. Food engineering and processing applications. Journal of Applied Science Publishers, 2(1):197-209, 1980.
SEKER, M. Selected properties of native or modified maize starch/soy protein mixtures extruded at varying screw speed. Journal of the Science of Food and Agriculture, 85(7):1161-1165, 2005.

SILVA, M. C.; CARVALHO, C. W. P.; ANDRADE, C. T. The effects of water and sucrose contents on the physicochemical properties of non-directly expanded rice flour extrudates. Ciência e Tecnologia de Alimentos, 29(3):661-666, 2009.

TRIBELHORN, R. E.; HARPER, J. M. Extruder: cooker equipment. Cereal Foods World, 25(4):154-156, 1980.

WEBB, P. A.; ORR, C. Analytical methods in fine particle technology. Micromeritics Instrument Corporation, 1997, $301 \mathrm{p}$.

WEBB, P. A. Volume and density determinations for particle technologist. Micromeritics Instrument Corporation, 2001, 16p. 
